\title{
Entomological Survey for Aedes Species at Deendayal Seaport, Kandla, Gujarat India during Pre-Monsoon Period, 2018
}

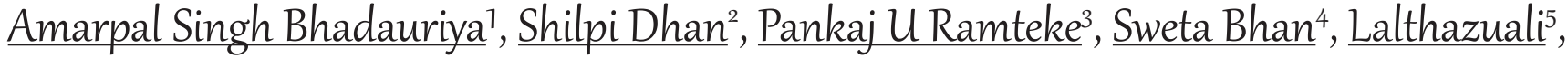 \\ Rina Kumawat ${ }^{6}$, Ram Singh ${ }^{7}$, Arun Chauhan ${ }^{8}$ \\ ${ }^{1}$ Shankarlal Agrawal Science College Salekasa, RTM University, Nagpur, India. \\ ${ }^{2}$ Centre for Medical Entomology \& Vector Management, NCDC, Delhi, India. \\ 3,4,5,6,7,8Tai Golwalkar Mahavidyalaya, Ramtek, RTM University, Nagpur, India. \\ DOI: https://doi.org/10.24321/0019.5138.202038
}

\section{I $\quad \mathbf{N} \quad \mathbf{F} \quad \mathbf{O}$}

Corresponding Author:

Amarpal Singh Bhadauriya, Shankarlal Agrawal

Science College Salekasa, RTM University,

Nagpur, India.

E-mail Id:

bhadauriya.amar@gmail.com

Orcid Id:

https://orcid.org/0000-0001-9960-9614

How to cite this article:

Bhadauriya AS, Dhan S, Ramteke PU, Bhan S, Lalthazuali, Kumawat $R$ et al. Entomological Survey for Aedes Species at Deendayal Seaport, Kandla, Gujarat India during Pre-Monsoon Period, 2018. J Commun Dis 2020; 52(4): 35-38.

Date of Submission: 2020-11-10

Date of Acceptance: 2020-12-12

\section{$\begin{array}{llllllll}\mathbf{A} & \mathbf{B} & \mathbf{S} & \mathbf{T} & \mathbf{R} & \mathbf{A} & \mathbf{C} & \mathbf{T}\end{array}$}

Entomological survey was conducted at Kandla international seaport, Kandla, Gujarat, India during pre-monsoon season of 2018 for immature Aedes mosquitoes. Standard entomological techniques were used for survey. All approachable larval breeding habitats were inspected. Inside seaport area, a total of 45 premises were searched for Aedes breeding out of which 02 premises were found inside area of seaport with 4.44 Premises Index (PI), 1.77 Container Index (Cl) and 4.44 Breteau Index (BI). Out-side area of seaport (non-residential), none of premises/ containers were found positive for breeding while in out-side residential area 27 were searched out of which 02 houses were found positive for Aedes breeding with 7.4 House Index ( $\mathrm{HI}), 8.10$ Container Index ( $\mathrm{Cl})$ and 11.11 Breteau Index (BI). Intermittent supply of water was the main reason for Aedes breeding in residential colony. From this study it is evident that inside port area and outside port area provided ample habitats for the mosquitoes to breed and thrive in wet season. Regular entomological surveillance is needed not only to monitor the Aedes mosquito breeding in and around port area including residential areas nearby but also to prevent the transportation and establishment of mosquito species in newer areas. Community awareness is also equally important to prevent entry of vector mosquito species in new areas.

Keywords: Aedes Aegypti, Dengue, Chikungunya, Zika, Premise Index, Container Index, Breteau Index

\section{Introduction}

According to International Health Regulations $2005,{ }^{1}$ it is every nation's responsibility to monitor regularly vector borne diseases at entry points like International airports and Seaports must be kept free from vector species of mosquitoes with in the radius of 400 meters. In recent years Vector-borne diseases (such as malaria, dengue, Chikungunya, Zika virus, yellow fever) becoming a serious problem in over 100 countries. According to World Health Organization approximate $60 \%$ of the world's population 
at risk of vector borne disease infection; more than 500 million cases are reported every year with more than 700,000 deaths from diseases such as malaria and other vector borne diseases. ${ }^{6}$ International travel and transport have played a major role in the rapid transmission of vectorborne diseases all over the world - as entry points such as International Airport and Seaport become more porous. ${ }^{2}$ Day by day the speed and extent of travel and shipping are increasing, so the potential of the transmission of vectorborne diseases are also increasing. The globalization and Industrialization and expansion of port cities has led to the global spread of Aedes aegypti and Aedes albopictus in countries. This has resulted in the spread of several diseases like yellow fever (Not reported from India till date), dengue, DHF, Chikungunya, and, in recent Zika virus in India and Asian countries. The transport of mosquitoes beyond their native range via shipping has been documented, particularly the expansion of A. albopictus via shipping of old tires $1 \& 5$. Since there is no proper treatment for dengue, zika and Chikungunya so environmental and ecosystem management is important strategy to prevent entry of vector species of mosquito. Presence and prevalence of mosquitoes in and around ports makes the issues more sensitive. Present study was undertaken during June 2018, at Kandla seaport, Gujarat, India, keeping in view of the large traffic at seaport in the form of cargo ships, because this port is busiest port in India.

\section{Materials and Methods}

\section{Study Area}

Kandla Port Trust or Deendayal Port is one of the major seaport situated in Kutch District of Gujarat state in western India, near the city of Gandhi Dham, Kandla has a desert climate. It is situated at Latitude 23ㅇ $01^{\prime} \mathrm{N}$ and Longitude 70 $13^{\prime} \mathrm{E}$ on the shores of the Kandla Creek which runs into the Gulf of Kutch at a distance of 90 nautical miles from the Arabian Sea., where it serves as critical gateway port for the western and north western hinterland of India on international trade routes to Middle East and Upper Gulf. It is the oldest port in India. The average annual temperature is $24.8^{\circ} \mathrm{C}$ and the average rainfall is $379 \mathrm{~mm}$. The port's share in traffic handled by all major ports has increasing continuously over the years. This port is handling about 83.74 million tons per annum. Kandla Port Trust, is the busiest major port in India in recent years, is gearing to add substantial cargo handling capacity with private sector participation.

\section{Nonresidential Area of Seaport}

Entomological survey of immature stages of vector of Dengue, Yellow Fever, Chikungunya and zika was carried out from inside areas of seaport viz. private jetty 9-12 and 15, KPT open plot, Gautam fright, Canteen, work-shop,
Rishi Shipping, Kandla open Plot, Berth N0. 9, West gate 2, Electric substation, Tilak fire station, Azad fire station, craft jetty 1 and 2, go down No. 2, 26, 27, 29 and 35, Canteen No. 1 \& 2, Marine Bhavan, West CISF gate, KPT tower No. 1 , Sea fearers office, surrounded areas, one vessel was surveyed and also from Oil Jetty area viz, Estate Office, Oil Jetty office, Security office area, KPT Fire brigade station, KPT office, Shastri jetty, Nehru jetty, Electric Substation, Fire brigade work shop, Fire storage tank area, Seafarer office Kandla, old RCC pier, Indira Jetty, Rajiv Jetty, Jetty No. 3 , Substation 11, Mini park, and water tank area. Detail of the survey is given in Table 1.

\section{Residential Area of Seaport}

Larval survey was also conducted in some those residential areas which are located within the 400-metre range of the seaport like Old Kandla labour colony and market area. In this area most of the labour who are working in seaport resident of this colony.

\section{Entomological Surveillance}

An entomological surveillance for immature and adult mosquitoes was undertaken in and around International seaport of Kandla during the post monsoon in the month of June 2018. Standard entomological techniques were used for survey. Larval sampling was conducted in all permanent/ temporary aquatic habitats of the Aedes mosquito. The breeding prevalence of Aedes mosquito was detected in different types of breeding containers. All accessible larval breeding habitats like discarded tires, metal drums, plastic drums, other metal containers, plastic buckets, flower pots, mud pots, cement tanks and other plastic containers were searched for immature stages of Aedes mosquito. Larvae and Pupae were collected, brought back to the laboratory, where they were kept for adult emergence. Adult mosquitoes emerged from the reared larvae/ Pupae were identified. To assess different types of breeding potential the collected data on immature stages were analyzed and calculated in terms of some important indices like Container Index $(\mathrm{Cl})$ : percentage of water-holding containers infested with larvae or pupae), House Index (HI): percentage of houses infested with larvae and/or pupae), Breteau Index (BI): number of positive containers per 100 houses inspected) as per the WHO procedure.7

\section{Results and Discussion}

\section{Larval survey}

Due to heavy international traffic, it is important to monitor all the airports and seaports according to IHR 2005 that area around the seaport within the radius of 400 meters must be free from vector species of mosquito specially Aedes species because it alone can transmit many diseases like Dengue, Chikungunya, Zika and Yellow fever (yet not reported from India) but we have experienced a large number of Zika 
outbreak in different states of India in the year 2018-19. Aedes aegypti is the main vector and Aedes albopictus is secondary vector of the dengue, Chikungunya etc. ${ }^{3}$

In view of the above an entomological survey was conducted in and around of the Kandla seaport, a total of 45 premises were searched for Aedes breeding out of which 02 premises were found inside area of seaport with 4.44 Premises Index (PI) and out of 171 containers were searched 02 containers were found positive for Aedes breeding with 1.77 Container Index $(\mathrm{Cl})$ and with 4.44 Breteau Index $(\mathrm{BI})$ in the same area. Out-side area of seaport (non-residential) were also searched for Aedes breeding a total of 28 premises and 139 containers were checked, none of premises/ containers were found positive (Table 1 ). Inside area of seaport mostly tires were found positive for Aedes breeding same result were shown by Reiter P. ${ }^{7}$

Survey was also conducted in residential area within the radius 400 meters near seaport, a total of 27 houses (whole colony contains only this much houses and some were found closed) were searched out of which 02 houses were found positive for Aedes breeding with 7.4 House Index ( $\mathrm{HI}$ ) and 37 wet containers were searched out of which 03 were found positive for Aedes breeding with 8.10 Container Index (CI) and 11.11 Breteau Index (BI). Most of positive containers were plastic containers used to fill water due to irregular supply of water (Table 1). In Oil jetty area, especially near water tank area one plastic tank was found positive for Aedes breeding and open drainage were found positive for Culex breeding. A large number of open cement tank were also found in most of the surveyed areas.

The plastic containers were used for holding water for daily use. Attempt was also made to catch adult mosquitoes and in MPT near civil site office high density of adult A. albopictus was noted with 78.0 Per Man Hour Density (PMHD).

\section{Mosquito Identification}

Larvae/ pupae were collected from all the surveyed areas were kept for adult emergence and on adult emergence these mosquitoes morphologically identified at the species level under a microscope identified as Aedes aegypti.

\section{Adult Mosquito Collection}

Adult mosquito collection was done by aspirator and torch method from human dwelling in Old Kandla labour colony. Two staffs were engaged for mosquito collection and 60 minutes was spent by each collector. Total time spent 120 minutes. The mosquito species collected and identified up to species level from the above-mentioned area, and data is furnished in Table 2.

Table 2.Results of adult mosquito collection in Old Kandla labour colony

\begin{tabular}{|c|c|c|c|c|}
\hline S. & \multirow{2}{*}{$\begin{array}{c}\text { Species } \\
\text { No. }\end{array}$} & \multicolumn{2}{|c|}{ No. of mosquitoes } & \multirow{2}{*}{ PMHD* } \\
\cline { 3 - 4 } & Male & Female & \\
\hline 1. & $\begin{array}{c}\text { Culex } \\
\text { quinquefasciatus }\end{array}$ & 7 & 10 & 8.5 \\
\hline 2. & Aedes aegypti & 2 & 6 & 4.0 \\
\hline
\end{tabular}

*Per man hour density.



Figure I.Potential Breeding sites at Seaport

\section{Conclusion}

It is concluded that a large number of open cement tank, tires, unused plastic, flower pot, empty discarded metallic junk material, iron containers, syntax tanks etc. were found in all the surveyed areas (Figure 1). They can be potential breeding sites for Aedes mosquito in rainy season. In residential area people had to fill water for daily use due to irregular supply of water. Anopheles breeding was also detected near the water supply office.

\section{Recommendation}

Large number of tyre/plastic and discarded junk material lying inside the seaport area which needs to be disposed off on priority basis to prevent Aedes breeding in the rainy season. Anti-larval operations should be strengthened both inside and outside port to curtail the mosquito breeding.

Table I.Result of survey done at Kandla Seaport (Residential \& non-residential areas)

\begin{tabular}{|c|c|c|c|c|c|c|c|}
\hline $\begin{array}{c}\text { Name of } \\
\text { area }\end{array}$ & $\begin{array}{c}\text { No. of } \\
\text { premises } \\
\text { searched }\end{array}$ & $\begin{array}{c}\text { No. of positive } \\
\text { premises/House }\end{array}$ & $\begin{array}{c}\text { Premises } \\
\text { Index/House } \\
\text { Index (PI/HI) }\end{array}$ & $\begin{array}{c}\text { No. of } \\
\text { Container } \\
\text { searched }\end{array}$ & $\begin{array}{c}\text { No. of } \\
\text { positive } \\
\text { containers }\end{array}$ & $\begin{array}{c}\text { Container } \\
\text { Index (CI) }\end{array}$ & $\begin{array}{c}\text { Breteau } \\
\text { Index (BI) }\end{array}$ \\
\hline $\begin{array}{c}\text { Inside area } \\
\text { of Seaport }\end{array}$ & 45 & 02 & 4.44 & 171 & 02 & 1.17 & 4.44 \\
\hline $\begin{array}{c}\text { Outside area } \\
\text { of Seaport }\end{array}$ & 28 & Nil & 0.0 & 139 & 0.0 & 0.0 & 0.0 \\
\hline $\begin{array}{c}\text { Residential } \\
\text { area }\end{array}$ & 27 & 02 & 7.4 & 37 & 03 & 8.10 & 11.11 \\
\hline
\end{tabular}


Excess water should be removed from the Planted pots. Awareness programmes regarding vector borne diseases among the peoples should be done every year. Regular anti larval activities may be carried out in these colonies to curtail the mosquito breeding further. Strict Bylaws may be enforced in nearby colonies to the seaport.

\section{Acknowledgement}

We are highly to the Director NCDC, Delhi for providing us this opportunity and also thankful to Dr. T.G. Thomas, Head Centre for Medical Entomology and Vector Management, NCDC, Delhi. We are also thankful to Dr. Sunil Prajapati, Chief Medical Officer Kandla and Mr. Mukesh Vasu (Administrative Officer Fire and Safety) for providing all needed support and assistance. The Authors are thankful to Mr. Subhash Chand Sharma (Technician) for providing technical support.

\section{Conflict of Interest: None}

\section{References}

1. Enserink M. Entomology: A mosquito goes global. Science 2008; 320: 864-70.

2. Lounibos LP. Invasions by insect vectors of human disease. Annual Review of Entomology 2002; 47: 23366.

3. Gould DJ, Yuill TM, Moussa MA, Simasathien P, Rutledge LC. An insular outbreak of dengue hemorrhagic fever. 3. Identification of vectors and observations on vector ecology. Am J Trop Med Hyg 1968; 17(4): 609-18.

4. Scholte EJ, Schaffner F. Waiting for the tiger: establishment and spread of the Asian tiger mosquito in Europe. In Takken W, Knols BGJ, eds. Emerging pests and vector-borne disease in Europe. Wageningen Academic Publishers, Wageningen. 2007.

5. World Health Organization. A global brief on vectorborne diseases. World Health Organization (WHO/ DCO/WHD/2019.1), Geneva. 2019.

6. World Health Organization. International Health Regulation (IHR). Available from: who.int/ publications/2008/9789241580410_eng.pdf. 1975.

7. Reiter P. Aedes albopictus and the world trade in used tires, 1988-1995: The shape of things to come. Journal of the American Mosquito Control Association 1998; 14: 83-94. 